\title{
THE EFFECT OF HEATING TEMPERATURE ON INHIBITORY ACTIVITY OF MANGROVE RHIZOPHORA MUCRONATA FRUIT EXTRACT TOWARD A-GLUCOSIDASE
}

\author{
HARDOKO ${ }^{1,2 *}$, BAMBANG B SASMITO ${ }^{1}$, YUNITA E PUSPITASARI ${ }^{1}$, YUYUN D OKVIANI ${ }^{1}$, YUNIWATY HALIM ${ }^{2}$
}

${ }^{1}$ Department of Fish Processing Technology, Faculty of Fisheries and Marine Sciences, Universitas Brawijaya, Jln. Veteran No. 1 Malang, Indonesia. ${ }^{2}$ Department of Food Technology, Universitas Pelita Harapan, Jl. MH Thamrin Boulevard 0-0, Lippo Karawaci, Tangerang, Indonesia. Email: hardoko@ub.ac.id/oko8163@yahoo.co

Received: 07 February 2017, Revised and Accepted: 07 April 2018

ABSTRACT

Objectives: The aim of this research was to determine the effect of heating temperature of mangrove Rhizophora mucronata fruit extract toward its inhibition activity of $\alpha$-glucosidase.

Methods: Research method used was an experimental method with the treatment of heating temperature $\left(70^{\circ} \mathrm{C}, 80^{\circ} \mathrm{C}, 90^{\circ} \mathrm{C}\right.$, and $\left.100^{\circ} \mathrm{C}\right)$ of $\mathrm{crude}$ tannin extract of mangrove $R$. mucronata fruit on inhibition activity toward $\alpha$-glucosidase.

Results: $\mathrm{IC}_{50}$ of unheated extract and extracts that were heated at $70^{\circ} \mathrm{C}, 80^{\circ} \mathrm{C}, 90^{\circ} \mathrm{C}$, and $100^{\circ} \mathrm{C}$ are adalah $3.38 \mathrm{ppm}, 2.79 \mathrm{ppm}, 2.97 \mathrm{ppm}, 3.19 \mathrm{ppm}$, and $3.52 \mathrm{ppm}$, respectively. Heating until $100^{\circ} \mathrm{C}$ only decreased its inhibition activity of $\alpha$-glucosidase of about $3.87 \%$ compared to unheated extract. Mangrove $R$. mucronata fruit extract contains phytochemical compounds, i.e., alkaloids, saponin, flavonoids, tannin, and terpenoids. IC $_{50}$ of this extract is lower compared to $\mathrm{IC}_{50}$ of acarbose (antidiabetic medicine), which as $\mathrm{IC}_{50}$ value of $13.27 \mathrm{ppm}$.

Conclusion: Mangrove R. mucronata fruit extract is quite heat resistant and is potential to be an antidiabetic functional food

Keywords: Rhizophora mucronata fruit extract, $\mathrm{IC}_{50}$, Heating temperature.

(C) 2018 The Authors. Published by Innovare Academic Sciences Pvt Ltd. This is an open access article under the CC BY license (http://creativecommons. org/licenses/by/4. 0/) DOI: http://dx.doi.org/10.22159/ajpcr.2018.v11i7.25175

\section{INTRODUCTION}

Diabetes mellitus is glucose metabolic disorder caused by the decrease in insulin effectiveness. The decrease in insulin secretion causes an increase in blood glucose level [1]. Increase in blood glucose level is also related to $\alpha$-glucosidase enzyme activity in intestine in carbohydrate digestion and glucose absorption by epithelium [2]. One of the methods to decrease blood glucose level on diabetes mellitus patient is by inhibiting $\alpha$-glucosidase enzyme and its activity on small intestine [3]. There are several in vitro researches that used a combination of $\alpha$-amylase and $\alpha$-glucosidase enzymes on various materials $[4,5]$. Inhibition toward $\alpha$-glucosidase is effective in decreasing glucose digestion and absorption in small intestine. Thus, it can lower the postprandial blood glucose level on diabetes mellitus patients [6]. Synthetic inhibitory agent in diabetes mellitus treatment is done by consuming acarbose and miglitol (diabetic medicine), but these synthetic inhibitory agents may cause side effects and increase the diabetes complication. Therefore, based on several experiments and scientific research of bioactive compounds, medicinal drugs from herbal sources are comparable to synthetic medicine [7]. Herbal products, both in forms of pure compounds or extract, have a chance to be developed in the area of medicine [8].

Since mangroves usually inhabit the transition zone between land and sea, it is expected that mangroves would be able to produce many natural products from their own secondary metabolites [9]. One of mangrove plants from Rhizophora mucronata type has secondary metabolites which are potential to become antidiabetic agents. Fruit part of black mangrove $R$. mucronata Lam has secondary metabolites, i.e., flavonoids, saponin, phenolic, hydroquinone, and tannins [10]. Crude extract of $R$. mucronata fruit was reported to be able to inhibit the activity of $\alpha$-glucosidase enzyme, and the extract contained flavonoids, saponin, steroid, and tannins [11]. It was also reported that fruit from $R$. mucronata in the forms of powder could cure the rats with type 2 diabetes [12]. Tannins are the main compounds in mangrove R. mucronata; therefore, it is suspected that tannins play an important role as an antidiabetic agent. Moreover, it was also reported that tannins are polyphenolic compounds that can also act as an antioxidant [13]. There is also a correlation between polyphenol and antioxidant and antidiabetic activity, such as in tea [14,15]

Phenolic antioxidant compounds that are relatively high can be considered as antidiabetic drugs [16]. The activity and composition of phenolic compounds and tannins are influenced by heating temperature. Heat processing could influence the stability of phenolic antioxidant compounds [17]. It is because generally antioxidant has a heat-labile property [18]. Study about the effect of temperature and $\mathrm{pH}$ is commonly done to determine the activity, stability and/ or characteristics of certain compounds, e.g., antioxidant activity of leek [19], antioxidant activity of rice bran [20], characteristics of tannin extract from Gambier [21], characteristics of color compound and tannin from guava leaves [22,23], and enzyme and flavonoid antimicrobe [24]. Besides, the process to obtain bioactive compounds is commonly done using heat and $\mathrm{pH}$. Therefore, it is required to do research to determine the effect of heating temperature toward inhibitory activity of $R$. mucronata extract toward $\alpha$-glucosidase enzyme.

\section{RESEARCH METHODS}

\section{Materials and equipment}

Materials used in this research consisted of materials for preparation of ripe mangrove $R$. mucronata fruit powder, extraction of ripe fruit from $R$. mucronata, characterization of temperature, total phenolic content, total tannin content, and total condensed tannin content and determination of inhibition activity toward $\alpha$-glucosidase. Materials used for the making of ripe mangrove $R$. mucronata fruit powder included ripe fruit of mangrove R. mucronata and $0.5 \%$ citric acid (Merck, Germany). Materials used for extraction of ripe mangrove 
R. mucronata fruit and temperature characterization were $70 \%$ acetone p.a. (v/v), 0.25\% ascorbic acid (Merck), aquadest, filter paper, aluminum foil, and dimethyl sulfoxide (DMSO). Materials used for the determination of total phenolic content, total tannin, and total condensed tannin were extract from ripe fruit $R$. mucronata, without temperature characterization (as a control) and with temperature characterization $\left(70^{\circ} \mathrm{C}, 80^{\circ} \mathrm{C}, 90^{\circ} \mathrm{C}\right.$, and $\left.100^{\circ} \mathrm{C}\right)$, Folin-ciocalteu, $7.5 \%$ $\mathrm{Na}_{2} \mathrm{CO}_{3}(\mathrm{w} / \mathrm{v})$, polyvinylpyrrolidone (PVPP), butanol-HCl (95:5), ferric reagent, and aquadest. Materials used for inhibitory activity assay toward $\alpha$-glucosidase were ripe mangrove $R$. mucronata fruit extract, $0.1 \mathrm{ml} \alpha$-glucosidase (Megazyme), substrate $\mathrm{p}$-4-Nitrophenyl $\beta$-Dglucopyranoside (PNPG) (Sisco Research Ltd.), DMSO and buffer pH, $200 \mathrm{mMNa}_{2} \mathrm{CO}_{3}$ (Merck), Bovine Serum Albumin (BSA) (Calbiochem), and $\mathrm{K}_{2} \mathrm{HPO}_{4}$.

\section{Methods}

The research method used was experimental methods with heating temperature of mangrove fruit extract as a treatment used to determine its effect on inhibitory activity toward $\alpha$-glucosidase. The temperature used was $70^{\circ} \mathrm{C}\left(\mathrm{A}_{1}\right), 80^{\circ} \mathrm{C}\left(\mathrm{A}_{2}\right), 90^{\circ} \mathrm{C}\left(\mathrm{A}_{3}\right)$, and $100^{\circ} \mathrm{C}\left(\mathrm{A}_{4}\right)$, also extract without any heating treatment $\left(\mathrm{A}_{0}\right)$. Heat treatment was applied on the extract after it was dissolved in DMSO solvent with ratio of 1:10 (w/v) and heat was applied for about $10 \mathrm{~min}$ [25].

\section{Preparation of mangrove $R$. mucronata fruit powder}

Main material used in the preparation of powder was mangrove R. mucronata ripe fruit. Ripe fruits were obtained from Nguling, Pasuruan district, East Java with characteristics as follows: The cotyledon has yellow color and the fruit has darker color. Fruit powder making started with cleaning and cutting the fruits to obtain $10 \mathrm{~cm}$ length and soaking them in $0.5 \%$ citric acid solution for $10 \mathrm{~min}$, draining and followed by blanching in hot water for $10 \mathrm{~min}$. After blanching, the fruits were then soaked in water for 3 days, drained and sun-dried for 2 days. After drying, mangrove fruit pieces were then milled using disc mill and sieved using 80 mesh sieve to obtain mangrove fruit powder [12].

\section{Extraction and temperature treatment of extract}

Extraction process was done based on the method by Zhou et al. [26], using sonicator with $40 \%$ amplitude. First, $25 \mathrm{~g}$ of mangrove fruit powder was dissolved using $70 \%$ acetone-water (v/v) and added with $0.25 \%$ ascorbic acid. This mixture was then sonicated for $30 \mathrm{~min}$ and centrifuged with $3000 \mathrm{rpm}$ speed for $10 \mathrm{~min}$ to obtain a supernatant as tannin crude extract. This crude extract was then heated using temperature of $70,80,90$, and $100^{\circ} \mathrm{C}$ for $10 \mathrm{~min}$. The observed parameters consist of yield, inhibition toward $\alpha$-glucosidase [27], total phenolic content [28], and total tannins [29].

\section{Inhibitory activity toward $\alpha$-glucosidase assay}

In vitro inhibition assay requires several materials, i.e., $\alpha$-glucosidase (Megazyme), substrate p-4-Nitrophenyl $\beta$-D-glucopyranoside (PNPG) (Sisco Research Ltd.), DMSO (Merck), $200 \mathrm{mM} \mathrm{Na}_{2} \mathrm{CO}_{3}$ (Merck), BSA (Calbiochem), and acarbose (PT. Bayer, Indonesia). Inhibitory activity toward $\alpha$-glucosidase was determined by enzymatic mixing reaction, consists of $10 \mu \mathrm{L}$ of sample in DMSO, $490 \mu \mathrm{L}$ phosphate buffer ( $\mathrm{pH} 7)$, and $250 \mu \mathrm{L}$ of $20 \mathrm{Mm}$ PNPG substrate, and homogenized using vortex. The mixture was then incubated at $37^{\circ} \mathrm{C}$ for $5 \mathrm{~min}$. Then, $250 \mu \mathrm{L}$ of $\alpha$-glucosidase solution was added (as $\mathrm{C}$ and $\mathrm{S}_{1}$ ), and $250 \mu \mathrm{L}$ of phosphate buffer was also added (as B and $\mathrm{S}_{0}$ ). Then, the mixture was incubated again at $37^{\circ} \mathrm{C}$ for $15 \mathrm{~min}$. The enzymatic reaction was stopped by adding $1000 \mu \mathrm{L}$ of $200 \mathrm{mM}$ sodium carbonate. This reaction would produce p-nitrophenol which has yellow color. The p-nitrophenol obtained from this reaction was then measured for its absorbance at $400 \mathrm{~nm}$ wavelength [27]. The enzymatic mixing reaction of $\alpha$-glucosidase can be observed in Table 1.

Percentage inhibition is calculated using formula: $\{(\mathrm{C}-\mathrm{S}) / \mathrm{C}\} \times 100 \%$, where $\mathrm{C}=$ absorbance of control (DMSO) without sample $(\mathrm{C}-\mathrm{B})$ and $\mathrm{S}=$ absorbance of sample $\left(\mathrm{S}_{1}-\mathrm{S}_{0}\right)$.
Acarbose solution was used as positive control. Acarbose solution was prepared by dissolving acarbose in buffer and $2 \mathrm{~N} \mathrm{HCl}$ (1:1) with concentration of $1 \%(b / v)$. The solution was centrifuged and the supernatant was used as a standard or positive control. $10 \mu \mathrm{L}$ of supernatant was taken and put inside the reaction mixture, such as in extract sample. Concentration of $R$. mucronata fruit extract used was $6.25 \mathrm{ppm}, 12.50 \mathrm{ppm}, 25.00 \mathrm{ppm}$, and $50.00 \mathrm{ppm}(\mathrm{w} / \mathrm{v})$ in DMSO solution.

\section{Determination of total tannin content}

Total tannins were determined using reaction between tannin compound and PVPP. About $100 \mathrm{mg}$ of PVPP was put inside reaction tube and added with $1 \mathrm{~mL}$ of aquadest and $1 \mathrm{~mL}$ of $R$. mucronata fruit extract, homogenized using vortex and incubated at a temperature of $4^{\circ} \mathrm{C}$ for $15 \mathrm{~min}$. The mixture was then homogenized using vortex and centrifuged ( $3000 \mathrm{rpm}$ for $10 \mathrm{~min}$ ). The obtained supernatant was used as total non-tannin phenolic. Total tannins were calculated using the formula: Total tannins $=$ total phenolic - total non-tannin phenolic [28] .

\section{RESULTS AND DISCUSSION}

\section{Yield and phytochemical content}

Yield is percentage obtained from the ratio between final weight and initial weight of sample, multiplied by $100 \%$. Yield calculation is used to determine the percentage of the extractable part from a raw material [16]. Ripe fruit from mangrove $R$. mucronata was made into powder before extraction process to increase the extraction rate and effectiveness. Characteristics of mangrove fruit powder obtained are brown color and fibrous. The fibers were then discarded using 60 mesh sieves to decrease the particle size of the raw material to ease the extraction process.

The increase in extraction effectiveness is influenced by size of material used, in which the smaller the particle size, the higher the surface area between the material and its solvent [30]. The yield data of ripe fruit $R$. mucronata crude extract and powder can be observed in Table 2. Qualitative analysis of crude tannin extract from mangrove leaves contain alkaloids, flavonoids, terpenoid, tannins, and saponin (Table 3). It is similar to results from crude methanol extract of black mangrove leaves [31], but in crude extract, tannins compound was more dominant

Table 3 shows that crude extract of $R$. mucronata fruits contains secondary metabolites, such as alkaloids, flavonoids, tannins, saponin, and triterpenoid, but it does not contain steroid. In correlation with blood glucose, triterpenoids, and saponin have been reported to be able to act as antibacterial, anti-inflammatory, antibiotics, hemolytic drug,

Table 1: Enzymatic mixing reaction system of $\alpha$-glucosidase

\begin{tabular}{|c|c|c|c|c|}
\hline Material & Blank $(\mu \mathrm{L})$ & Control $(\mu \mathrm{L})$ & $S_{0}(\mu L)$ & $S_{1}(\mu L)$ \\
\hline Sample & - & - & 10 & 10 \\
\hline DMSO & 10 & 10 & - & - \\
\hline Phosphate buffer pH 7 & 490 & 490 & 490 & 490 \\
\hline Substrate & 250 & 250 & 250 & 250 \\
\hline $\begin{array}{l}\text { Incubated in water } \\
\text { bath }\left(37^{\circ} \mathrm{C} \text { for } 5 \mathrm{~min}\right)\end{array}$ & & & & \\
\hline Phosphate buffer pH 7 & 250 & - & 250 & - \\
\hline $\begin{array}{l}\text { Enzyme } \\
\text { Incubated in water } \\
\text { bath }\left(37^{\circ} \mathrm{C} \text { for } 15 \mathrm{~min}\right)\end{array}$ & - & 250 & - & 250 \\
\hline $\mathrm{Na}_{2} \mathrm{CO}_{3}$ & 1000 & 1000 & 1000 & 1000 \\
\hline
\end{tabular}

Table 2: Yield of powder and crude extract of $\boldsymbol{R}$. mucronata fruit

\begin{tabular}{ll}
\hline Product & Yield (\%) \\
\hline Fruit powder & 26.11 \\
Crude extract & 11.83 \\
\hline
\end{tabular}

R. mucronata: Rhizophora mucronata 
and hypoglycemic drug and has cytotoxic activity [32]. Flavonoids can be used as antidiabetic [26] and have been introduced as hypolipidemic and antioxidant for rats that have been STZ-induced [33]. Tannins from mangrove plant have stronger antioxidant activity compared to BHT standard. Therefore, they are also potential to become antidiabetic [34].

Effect of heat treatment of extract on its inhibitory activity toward $\alpha$-glucosidase

Inhibitory activity toward $\alpha$-glucosidase by extract is expressed as $\mathrm{IC}_{50}$, i.e. the ability of extract to inhibit $50 \%$ of enzyme activity. The lower the $\mathrm{IC}_{50}$ value, the higher the inhibitory activity, and vice versa. Analysis of variance (Anova) result shows that heat treatment on extract gave significant difference $(\mathrm{p}<0.05)$ on $\mathrm{IC}_{50}$ value. Results from post hoc test using Tukey can be observed in Fig. 1.

It can be seen from Fig. 1 that heating until $90^{\circ} \mathrm{C}$ increases the inhibitory activity of extract toward $\alpha$-glucosidase, shown by lower $\mathrm{IC}_{50}$ value compared to $\mathrm{IC}_{50}$ value of unheated extract (control). This result indicates that heating until $90^{\circ} \mathrm{C}$ could increase the inhibitory activity related to exposure of functional group from compounds inside the extract that plays a role in inhibiting the enzyme. The highest increase in inhibitory activity toward $\alpha$-glucosidase occurs in heat treatment at $70^{\circ} \mathrm{C}$, which then decrease until heat treatment of $90^{\circ} \mathrm{C}$. This decrease is suspected caused by the damage of functional group that plays a role in inhibiting $\alpha$-glucosidase activity. The highest inhibitory activity at $70^{\circ} \mathrm{C}$ supported the previous research who reported that brewing temperature of $70^{\circ} \mathrm{C}$ on black tea gave highest inhibitory effect (96.76\%) compared to brewing temperature of $100^{\circ} \mathrm{C}(91.03 \%)$ [35]. The similar result was also reported on green tea brewing [36].

Heat treatment until $100^{\circ} \mathrm{C}$ caused decrease in inhibitory activity of about 3.87\% compared to unheated extract (Fig. 2). The slight decrease is suspected caused by tannins activity in extract. Tannins are parts of polyphenol compounds inside cell vacuoles which could act as an antioxidant. Tannins are more soluble when heated at high temperature.

Table 3: Phytochemical results of R. mucronata fruits powder

\begin{tabular}{ll}
\hline Analysis & Result \\
\hline Alkaloids & + \\
Mayer & + \\
$\quad$ Dragendorff & + \\
Flavonoids & +++ \\
Tannins & + \\
Saponin & + \\
Triterpenoid & - \\
Steroid & \\
\hline
\end{tabular}

+: Detected, -: Not detected. R. mucronata: Rhizophora mucronata

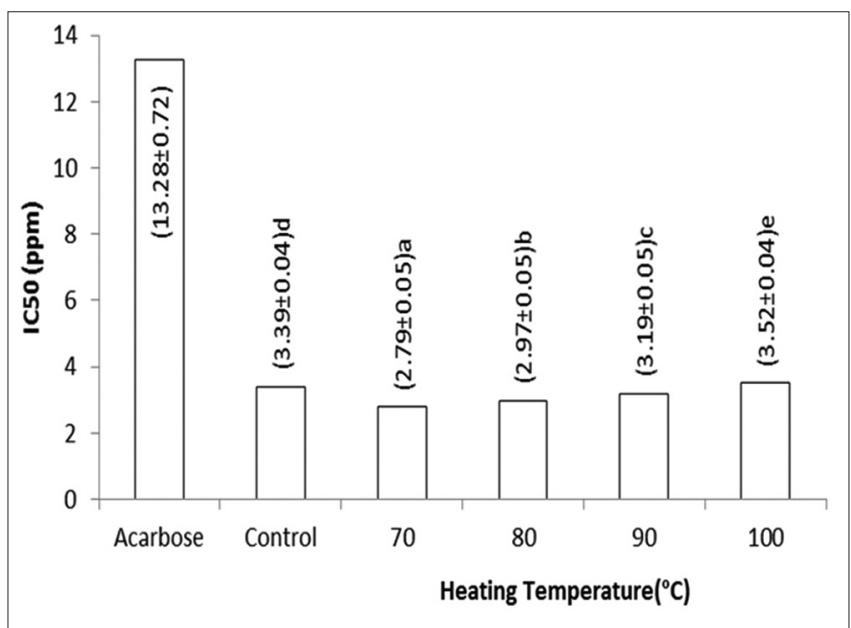

Fig. 1: Effect of heating temperature on $\mathrm{IC}_{50}$ value of Rhizophora mucronata fruit crude extract
This is supported by previous research which reported that heating at higher temperature would result in the high amount of tannins [37]. However, the quality of tannins obtained was lower because soluble tannins content was also higher.

To determine the change in inhibitory activity of extract toward $\alpha$-glucosidase caused by heat treatment, percentage of change in $\mathrm{IC}_{50}$ value compared to control was calculated, as can be seen on Fig. 2 . Positive value indicates the increase in inhibitory activity, whereas negative value indicates the decrease in inhibitory activity toward $\alpha$-glucosidase. Heating of extract until $70^{\circ} \mathrm{C}$ increases the percentage of inhibition, compared to unheated extract, with increase percentage of $17.63 \%$, whereas heating of extract until $100^{\circ} \mathrm{C}$ decreases the inhibitory activity for about (3.87\%). It is because high-temperature treatment could degrade tannins compound in the extract.

R. mucronata fruit extract contains major bioactive compound, i.e., tannins, which are believed to be able to inhibit the activity of $\alpha$-glucosidase. Tannins are polyphenol compounds that can precipitate protein. Enzyme is a protein that can catalyze biological reactions. Addition of tannins in enzymatic reaction of $\alpha$-glucosidase could precipitate protein because protein-tannins will form complex bond and as a result, the enzyme will not be able to degrade substrate. Thus, the activity of $\alpha$-glucosidase could be inhibited. Inhibition of $\alpha$-glucosidase by catechins was caused by the formation of complex bond between protein and phenols, which is caused by hydrogen bond between hydroxyl group and $-\mathrm{NH}$ and -CO groups of protein [36].

\section{Total phenolic content}

Total phenolic content in this research was determined using FolinCiocalteu reagent. This method is based on reducing power of phenolic hydroxyl group. The standard used in this assay was Gallic acid. Statistical analysis result (Anova) shows that heat treatment of extract gave significant effect $(\mathrm{p}<0.05)$ on total phenolic content. Result from post hoc test using Tukey can be observed in Fig. 3.

Fig. 3 in general shows that total phenolic content of heated extract is higher than unheated extract (control). It is suspected caused by the change in chemical functional group or opening of phenolic functional group, as a result from heat treatment. The highest total phenolic content occurs on extracts that were heated at a temperature of $70^{\circ} \mathrm{C}$ and $80^{\circ} \mathrm{C}$, and then decrease on extracts that were heated at temperature of $90^{\circ} \mathrm{C}$ and $100^{\circ} \mathrm{C}$. The decrease in total phenolic compound might be because there is a phenolic compound that is sensitive to heat. One of phenolic compounds, i.e., procyanidin, is highly degraded on heating at $98^{\circ} \mathrm{C}$ for $90 \mathrm{~min}$ and $120^{\circ} \mathrm{C}$ for $20 \mathrm{~min}$ [37]. However, there are also many phenolic compounds which are heat stable and have boiling point of about $181.7^{\circ} \mathrm{C}$, and even there are some phenolic compounds that can only be degraded at heating above $300^{\circ} \mathrm{C}$ [38]. Phenolic compounds that are oxidized will produce several products, i.e., p-benzoquinone, dicarboxylic acid and carbon dioxide.

If this result is correlated to $\mathrm{IC}_{50}$ value (Fig. 4), heating of extract at $70^{\circ} \mathrm{C}$ results in lowest $\mathrm{IC}_{50}$ value or highest inhibitory activity toward $\alpha$-glucosidase. Thus, it can be concluded that polyphenol compounds in extract play a role in inhibiting $\alpha$-glucosidase.

\section{Total tannin content}

Statistical analysis result (Anova) shows that heat treatment of extract gave significant effect $(\mathrm{p}<0.05)$ on total tannin content. The result from post hoc test using Tukey can be observed on Fig. 4. The phenomenon of heat treatment effect on total tannins is similar to that of total phenolic, in which heating process increases total tannin content and the highest total tannin content occurs in the extract that was heated at $70^{\circ} \mathrm{C}$ and even until heating temperature of $90^{\circ} \mathrm{C}$. It means heating process until $90^{\circ} \mathrm{C}$ could open tannins groups, which makes them detected as total tannins. Heating process could denature protein that binds tannins to release the tannins [39]. Moreover, during blanching, there was denaturation of protein that caused tannins to be released from protein [40]. 


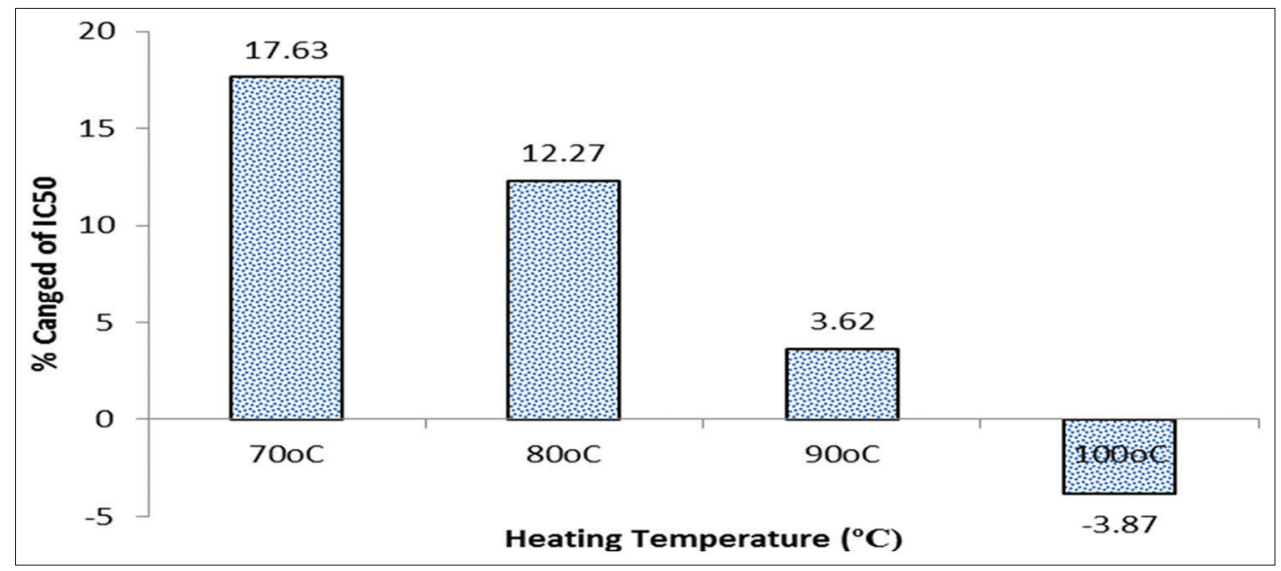

Fig. 2: The percent change of IC ${ }_{50}$ of Rhizophora mucronata extract on different heating temperature

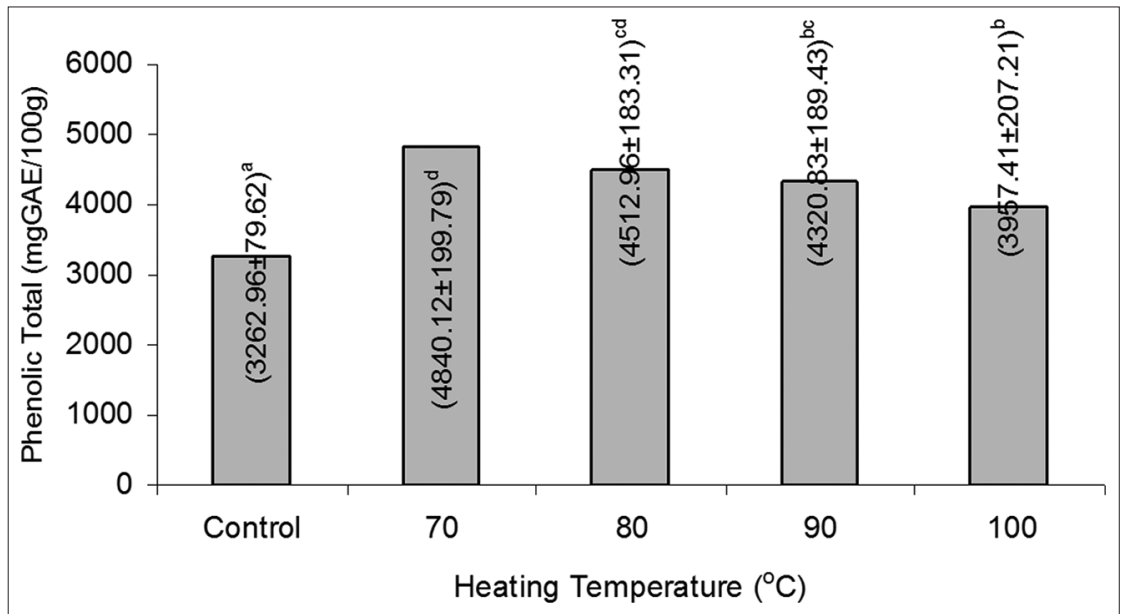

Fig. 3: Total phenolic content of Rhizophora mucronata crude extract on different heating temperature

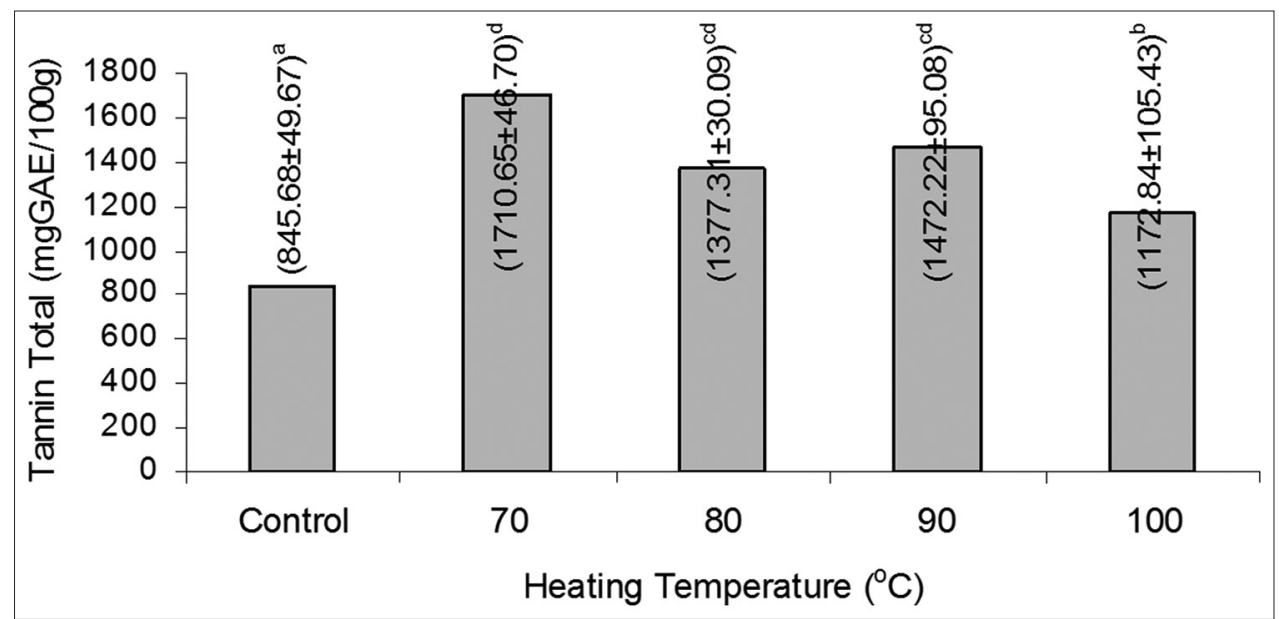

Fig. 4: Total tannins of Rhizophora mucronata crude extract on different heating temperature

In total tannin content, there is another compound, such as hydrocolloids [41,10]. The range of total tannins was higher than previous research, which stated that total tannins of $R$. mucronata fruit extract were about $6.20 \mathrm{mg} / \mathrm{g}$ [42]. If the result is correlated to extract activity in inhibiting $\alpha$-glucosidase enzyme (Fig. 1), it shows that high total tannins (on heating at $70^{\circ} \mathrm{C}$ ) give low $\mathrm{IC}_{50}$ value or high inhibitory activity toward $\alpha$-glucosidase. Tannins have high ability to denature protein $[43,42]$. This strengthens the indication that tannins could inhibit $\alpha$-glucosidase or in other words, tannins are potential to be functional antidiabetic agent.

\section{CONCLUSIONS}

Heat treatment toward R. mucronata crude fruit extract until $100^{\circ} \mathrm{C}$ could increase its inhibitory activity toward $\alpha$-glucosidase with the highest inhibitory activity was with heat treatment of $70^{\circ} \mathrm{C}$ with $\mathrm{IC}_{50}$ of $2.790 \pm 0.051 \mathrm{ppm}$.

R. mucronata crude fruit extract is quite stable toward heat with heat treatment until $100^{\circ} \mathrm{C}$ only decreased its inhibitory activity toward $\alpha$-glucosidase for about $3.67 \%$. 
Inhibitory activity of $R$. mucronata crude fruit extract toward $\alpha$-glucosidase was higher compared to acarbose, makes it potential to become natural antidiabetic drugs.

\section{REFERENCES}

1. Furukawa S, Fujita T, Shimabukuro M, Iwaki M, Yamada Y, Nakajima Y, et al. Increased oxidative stress in obesity and its impact on metabolic syndrome. J Clin Invest 2004;114:1752-61.

2. Febrinda A, Made A, Tutik W, Nancy DY. Capacity of antioxidant and alpha glucosidase inhibitor of Onion Dayak extract. J Teknol Ind Pangan 2013;24:161-7.

3. Mataputuna SP, Roronga JA, Pontoha P. Activity of $\alpha$-glucosidase inhibitor of matoa bark extract (Pometia pinnata spp.) as antihyperglycemic agent. J MIPA UNSRAT 2013;2:119-23.

4. Khatri DK, Juvekar AR. $\alpha$-glucosidase and $\alpha$-amylaseinhibitory activity of Indigofera cordifolia seeds and leaves extract. Int J Pharm Pharm Sci 2014;6:152-5.

5. Reka P, Banu AT, Seethalakshmi M. Alpha amylase and alpha glucosidase inhibition activity of selescted edible seaweeds from South Coast Area of India. Int J Pharm Pharm Sci 2017;9:64-8.

6. Rais IR, Samudra AG, Widyarini S, Nugroho AE. Determination of andrografolid isolate activity against $\alpha$-amylase and $\alpha$-glucosidase using apostolidis method. Trad Med J 2013;18:162-6.

7. Pasaribu G. Inhibitory activity of alpha glucosidase in some types of Raru bark. J Penelitian Hasil Hutan 2010;29:10-9.

8. Parthasarathy S, Azizi JB, Ramanathan S, Ismail S, Mansor SM, Sasidharan S, et al. Evaluation of antioxidant and antibacterial activities of aqueous, methanolic, and alkaloid from Mitragyna speciosa (Rubiaceae Family) leaves. Mol J 2009;14:3964-74.

9. Salini G. Pharmacological profile of mangrove endophytes-a review. Int J Pharm Pharm Sci 2015;7:6-15.

10. Purwaningsih S, Ella S, Aditya YP, Eka D. Antioxidant activity of mangrove fruit (Rhizophora mucronata Lamk.) at different temperatures. J Masyarakat Pengolahan Hasil Perikanan Indonesia 2013;16:199-206.

11. Hardoko, Puspitasari YE, Suprayitno E. $\alpha$-Glucosidase inhibitory activities of Rhizophora mucronata fruit powder. Int J ChemTech Res 2015;8:211-5

12. Hardoko, Suprayitno E, Puspitasari YE, Amalia R. Study of ripe Rhizophora mucronata fruit flour as functional food for antidiabetic. Int Food Res J 2015;22:953-9.

13. Rosida DF, Sudaryati HP, Apriliyanti NF. Physico-chemical characteristics and antioxidant activity of tauco Lamtoro Gung (Leucaena leucocephala) Angkak. J Rekapangan 2014;8:156-64.

14. Sheikh RE, Amin AS, Atwa MA, Gouda AA, Abdullah AA. Determination of phenolic component and antioxidant activity of some Egyptian tea samples. Int J Pharm Pharm Sci 2015;7:198-202.

15. Widyawati PS, Werdani YD, Setiokusumo C, Kartikasari A. In vitro antioxidant capacities and antidiabetic properties of Pluchea leaves and green tea mixtures at various proportions. Int J Pharm Pharm Sci 2017;9:203-8

16. Malangngi LP, Meiske SS, Jessy, Paendong JE. Determination of tannin content and antioxidant activity test of avocado seed extract (Persea americana Mill.) J MIPA UNSRAT 2012;1:5-10.

17. Suryanto E, Lidya IM, Mercy T, Frenly W. Potential antioxidant polyphenol compounds from Goroho banana (Moses sapien sp.). J Agritech 2011;31:289-96.

18. Husna NE, Novita M, dan Rohaya S. The content of anthocyanin and antioxidant activity of fresh purple sweet potato and its processed products. J Agritech 2013;33:296-302.

19. Siregar TM, Eveline, Jaya FA. Study of the Activity and Stability of Antioxidant Crude Extracts of Leek (Allium fistulosum L.). Semarang, Indonesia: Prosiding SNST ke-6 Fakultas TeknikUniversitas Wahid Hasyim; 2015. p. 36-43.

20. Widarta IW, Arnata IW. Stability of antioxidant activity of red rice bran extract subjected to oxidator and heating in various $\mathrm{pH}$. J Teknol Ind Pangan 2014;25:193-9.

21. Muchtar H. Influence of sodium addition in precipitation process of Gambier treatment wastewater to tannin yield. J Litbang Ind 2013;3:59-65

22. Sukardi A, Mulyarto R, Safera W. Determination of an optimum extraction time and its production cost of powdered extract of Guava (Psidii folium) Leaf. J Teknol Pertanian 2007;8:88-94

23. Pardede L, Kusdiyantini E, Budiharjo A. Extraction and test stability of color dried leaf guava seeds (Psidium guajava L.). J Biol 2014;3:9-15.

24. Soeka YS, Naiola E, Sulistyo J. Antimicrobial activity of synthesized flavonoid-glycoside through enzymatic transglicosylation. Berita Biol 2007;8:455-64.

25. Mayani L, Sudarmnito SY, Dian WN. The effect of ginger size reduction and water ratio to physical and chemical properties of organoleptic on ginger extract (Zingiber officinale). J Pangan Agro Ind 2014;2:148-58.

26. Zhou HC, Nora FT, Yi ML, Shu DW, Yuan YL. Changes of condensed tannins during decomposition of leaves of Kandelia obovata in a subtropical mangrove Swamp in China. J Soil Biol Biochem 2012;44:113-21.

27. Sugiwati S, Siswati S, Efi A. Antihyperglycemic activity of the Mahkota Dewa (Phaleria macrocarpa (Scheff)) leaf extracts as an alpha-glucosidase inhibitor. J Makara Kesehatan 2009;13:74-8.

28. Haron N, Raob N. Changes in macronutrient, total phenolic and anti-nutrient contents during preparation of tempeh. J Nutr Food Sci 2014;4:1-5.

29. FAO. Quantification of Tannis in Tree Foliage. Vienna: Working Document IAEA; 2002.

30. Mutiara EV, Wildan A. Extraction of flavonoids from pare leaves (Momordica charantia $\mathrm{L}$ ) with microwaves as an in vitro glucoselowering. Metana 2014;10:1-11.

31. Paryanto, Utama AD, Rahmadita F, Trisna R. Intake of natural dyestuff from Rhizophora mucronata mangrove fruit extraction of three-stage batch liquid in a pilot plant scale. Momentum 2017; 13(2): 5-10.

32. Bandaranayake WM. Bioactivities, bioactive compounds and chemical constituents of mangrove plants. Wetl Ecol Manag 2002;10:421-52.

33. Keshari AK, Kumar G, Kushwaha PS, Bhardwaj M, Kumar P, Rawat A, et al. Isolated flavonoids from Ficus racemosa stem bark possess antidiabetic, hypolipidemic and protective effectsin albino wistar Rats. J Ethnopharm 2016;181:252-62.

34. Uddin N, Hasan R, Hossain M, Sarker A, Hasan N, Islam M, et al. In vitro $\alpha$-amylase inhibitory activity and in vivo hypoglycemic effect of methanol extract of Citrus macroptera Montr. fruit. Asian Pac J Trop Biomed 2014;4:473-9.

35. Christianty FM. In vitro $\alpha$-glucosidase inhibitory activity of various tea (Camellia sinensis L.) extract. ProcICMHS 2016;2016:104-7.

36. Julian AR. Effect of Temperature and Duration of Brewing of Green Tea (Camellia sinensis) and in vitro Digestion Process on Inhibition of Alpha Amylase and Alpha Glucosidase Enzyme Activity by in vitro. Bogor: Thesis IPB; 2011. p. 1-2.

37. Bijaksana MI. Effect of Temperature and Time of Black Tea Brewing (Camellia sinensis) and in vitro Digestion Process on Lipase Inhibition Activity. Bogor: Thesis IPB; 2012. p.1-3.

38. Wiranata G, Sudarminto SY, Indria P. The influence of old timber and drying temperature on the quality of the product dye anna apple (Malus domestica). J Pangan Agro Ind 2016;4:449-57.

39. Enny K, Fadillah Y. The effect of rotation speed of stirring and operating temperature on tannin extraction from cashew with acetone solvent. Ekuilibrium 2007;6:33-7.

40. Pujimulyati D, Sri R, MarsonoY, Umar S. The effect of blanching on antioxidant activity, phenol levels, flavonoids, and tannins are condensed Kunir Putih (Curcuma mango Val.). J Agritech 2010;30:141-7.

41. Hamidah S. The yield and content of mangrove bark tannins (Rhizophora mucronata Lamck) from Takisung Region. J Hutan Trop Borneo 2006;18:15-23.

42. Sasongko WT, Lies MY, Zaenal, Mugiono B. Optimization of tannin of jack fruit leaf with bovine serum albumin protein. Buletin Peternakan 2010; 34(3):154-158. 